\title{
Climate and Consumption Pattern -Demand and Supply of Water District concessionaires
}

\author{
Edilyn Audar, Alyssa Genikka Avendaño, Jessa Marie Granada, Charmaine \\ Alpha Padilla, Felipe Balaria
}

\begin{abstract}
This study aimed to describe the climate and consumption pattern-demand and supply in Santa Rosa, Nueva Ecija of Water District Concessionaires from the year 2016-2018. It looked into which season and year have a high or low water supply and consumption. The descriptive research design was utilized and gathered data were primarily taken from the Monthly Data Sheet from Production Division of Santa Rosa (N.E.) Water District. The demand presented the meter billed while the supply illustrated the production of the Santa Rosa (N.E.) Water District. The study revealed that the concessionaires were consuming more in the dry season rather than in the rainy season. They have the highest water supply in 2018 with 3,355,162 cubic meters while 2016 has the lowest with 2,792,392 cubic meters. As to the percentage consumption, the respondents consume $82.37 \%$ of supply in $2018(2,763,679 / 3,355,162 x 100 \%), 86.44 \%$ in $2017(2,581,267 / 2,986,165 x 100 \%)$ and $85.13 \%$ in 2016 which disclosed that the respondents consume more water percentage in 2017 than in 2016 and 2018.
\end{abstract}

Keywords-Climate change, flooding, Government-Owned Controlled Corporation.

\section{INTRODUCTION}

Climate change is an inevitable event that happens because of pollution. It is a change in global or regional climate patterns. It affects water reserves especially in tropical countries such as the Philippines. When summer season, water reserves tend to evaporate quickly because of excessive heat trapped by the greenhouse effect in the ozone layer and when it's a rainy season to much rain pours in the sky that results in flooding in the lower places in the Philippines; thus, water reserves tend to replenish too much the limit of a dam can hold [1].

Water is an essential need for human life because up to $60 \%$ of the human body is made up of water. It is so essential because we cannot live without water. We use it in our daily activities such as taking a bath, washing clothes and dishes, and etc. [2].

Santa Rosa (NE) Water District is a Government-Owned Controlled Corporation (GOCC) and is an autonomous unit politically and economically independent from the local government. The Board of Directors formulated the policies, rules and regulations of the water district. Management of the operation of the water district is handled by the General Manager who is appointed by the Board of Directors [3].As of December 2019, the district has a total of 12,059 service connections operating 24 hours a day. Through the hard work and dedication of its personnel, SRWD was able to withstand the hardships and challenges of times and was able to make use of its resources in order to achieve its goal and objectives in giving the best water service to the people of Santa Rosa [3]. In Santa Rosa(N.E) Water District, water reserves come from the groundwater which is easily depleted as the rate of recharge of deep wells is less than the Consumption of the concessionaires.

The usage of water is greatly affected by the changes in climate because people will tend to use more water when the season is summer and tend to consume less when its rainy season.

This research shows the climate and supply and consumption pattern of Santa Rosa (N.E.) Water District concessionaires and to see which season has a high or low consumption/supply in two seasons.

\section{METHODOLOGY}

This study utilizeda descriptive research design wherein the monthly water consumption and supply data were gathered through the monthly datasheet from 2016 to 2018.According to [4] as cited in [5], a "descriptive survey can systematically 
describe a situation, problem, phenomenon, service or programs, or provide information or describe the attitude towards an issue". Selected concessionaires who were chosen purposively [6]were asked about their consumption and supply patterns. The data were analyzed using frequency and percentage.

\section{RESULTS AND DISCUSSION}

\section{Temperature and Rainfall from 2016-2018}

Table 1. Average Temperature and Rainfall for 2016-2018 [7]

\begin{tabular}{|c|c|c|c|}
\hline \multirow[b]{2}{*}{ Month } & \multicolumn{2}{|c|}{ Temperature ${ }^{\circ} \mathrm{C}$} & \multirow{2}{*}{$\begin{array}{l}\text { Rainfall } \\
\left(\mathrm{m}^{3}\right)\end{array}$} \\
\hline & Minimum & Maximum & \\
\hline January & 17.4 & 33.2 & 0.0 \\
\hline February & 17.0 & 34.5 & 5.4 \\
\hline March & 19.4 & 37.0 & 2.5 \\
\hline April & 19.4 & 38.8 & 0.2 \\
\hline May & 21.8 & 38.5 & 90.7 \\
\hline June & 22.0 & 36.7 & 297.6 \\
\hline July & 22.0 & 34.7 & 513.4 \\
\hline August & 22.6 & 33.6 & 552.8 \\
\hline September & 22.2 & 33.1 & 993.7 \\
\hline October & 21.0 & 35.0 & 514.1 \\
\hline November & 19.3 & 33.6 & 33.9 \\
\hline
\end{tabular}

\begin{tabular}{|l|l|l|l|} 
December & 19.0 & 35.1 & 16.2 \\
\hline TOTAL & $\mathbf{2 4 3 . 1}$ & $\mathbf{4 2 3 . 8}$ & $\mathbf{3 0 1 8 . 0}$ \\
\hline Average & $\mathbf{2 0 . 3}$ & $\mathbf{3 5 . 3}$ & $\mathbf{2 5 1 . 5}$ \\
\hline
\end{tabular}

The table shows that the average that rainy season falls between the months of June - October with a monthly average rainfall of $574.22 \mathrm{~m}^{3}$ and the average annual temperature ranges between $20.26^{\circ} \mathrm{C}$ and $35.32^{\circ} \mathrm{C}$. March, April and May are the dry and hot months, marked by an almost absence of rain and temperature reads at an average of $30^{\circ} \mathrm{C}$.

\section{Monthly Consumption and Supply from 2016-2018}

Table 2 shows that 2018 has the highest supply of water with 3,355,162 cubic meters while 2016 has the lowest with $2,792,392$ cubic meters. As to the consumption, the respondents consume $82.37 \%$ of supply in 2018 $(2,763,679 / 3,355,162 x \quad 100 \%), \quad 86.44 \%$ in 2017 $(2,581,267 / 2,986,165 \times 100 \%)$ and $85.13 \%$ in 2016 . This finding shows that the respondents consume more water in 2017 than in 2016 and 2018.

The table alsoreveals the consumption and supply of 2016 with a peak of consumption and supply in July which is $211,267 \mathrm{~m}^{3}$ and $253,995 \mathrm{~m}^{3}$, respectively, it shows that even in rainy season consumption and supply of water is still in rising but there is a large amount of usage in water between the month of March-Maywith an average of $202,915 \mathrm{~m}^{3}$ while the average monthly usage of January, February and JuneDecember is lower with an average monthly consumption of $196,476 \mathrm{~m}^{3}$ shows that more concessionaires are consuming in the dry season rather than Rainy Season.

Table 2.Monthly Consumption and Supply for 2016-2018 [8]

\begin{tabular}{|l|l|l|l|l|l|l|}
\hline & \multicolumn{2}{|c|}{2016} & \multicolumn{2}{c|}{2017} & \multicolumn{2}{c|}{2018} \\
\hline MONTHS & $\begin{array}{c}\text { CONSUMPTI } \\
\text { ON (METER } \\
\text { BILLED) in } \\
\mathbf{m 3}\end{array}$ & $\begin{array}{c}\text { SUPPLY } \\
\text { (PRODUCTIO } \\
\text { N) in } \mathbf{~ m 3}\end{array}$ & $\begin{array}{c}\text { CONSUMPTI } \\
\text { ON (METER } \\
\text { BILLED) in } \\
\mathbf{m 3}\end{array}$ & $\begin{array}{c}\text { SUPPLY } \\
\text { (PRODUCTIO } \\
\text { N) in m3 }\end{array}$ & $\begin{array}{c}\text { CONSUMPTI } \\
\text { ON (METER } \\
\text { BILLED) in } \\
\mathbf{m 3}\end{array}$ & $\begin{array}{c}\text { SUPPLY } \\
\text { (PRODUCTIO } \\
\text { N) in m3 }\end{array}$ \\
\hline JANUARY & 184,978 & 222,992 & 189,968 & 228,672 & 202,319 & 251,420 \\
\hline $\begin{array}{l}\text { FEBRUAR } \\
\text { Y }\end{array}$ & 179,400 & 215,950 & 187,781 & 214,484 & 210,695 & 260,718 \\
\hline MARCH & 208,319 & 242,896 & 218,458 & 257,926 & 233,834 & 285,571 \\
\hline APRIL & 210,238 & 238,571 & 228,665 & 250,610 & 239,291 & 298,514 \\
\hline
\end{tabular}




\begin{tabular}{|l|l|l|l|l|l|l|}
\hline MAY & 190,188 & 230,068 & 225,279 & 250,479 & 243,840 & 303,828 \\
\hline JUNE & 204,254 & 238,764 & 216,621 & 244,876 & 228,545 & 285,588 \\
\hline JULY & 211,267 & 253,995 & 214,347 & 249,119 & 225,608 & 273,590 \\
\hline AUGUST & 190,193 & 228,218 & 222,751 & 252,924 & 235,787 & 290,646 \\
\hline $\begin{array}{l}\text { SEPTEMBE } \\
\text { R }\end{array}$ & 194,033 & 226,025 & 208,293 & 248,340 & 226,708 & 268,107 \\
\hline OCTOBER & 205,481 & 235,447 & 235,750 & 264,800 & 244,232 & 283,995 \\
\hline $\begin{array}{l}\text { NOVEMBE } \\
\text { R }\end{array}$ & 185,867 & 222,698 & 191,999 & 239,724 & 218,491 & 270,710 \\
\hline $\begin{array}{l}\text { DECEMBE } \\
\text { R }\end{array}$ & 212,811 & 236,768 & 241,355 & 284,211 & 254,329 & 282,475 \\
\hline TOTAL & $\mathbf{2 , 3 7 7 , 0 2 9}$ & $\mathbf{2 , 7 9 2 , 3 9 2}$ & $\mathbf{2 , 5 8 1 , 2 6 7}$ & $\mathbf{2 , 9 8 6 , 1 6 5}$ & $\mathbf{2 , 7 6 3 , 6 7 9}$ & $\mathbf{3 , 3 5 5 , 1 6 2}$ \\
\hline
\end{tabular}

As to the consumption and supply of 2017, with a peak of consumption and supply in December which is $241,355 \mathrm{~m}^{3}$ and $284,211 \mathrm{~m}^{3}$, respectively, it shows that even in rainy season consumption and supply of water is still in rising but there is a large amount of usage in water between the month of March-May with an average of $224,134 \mathrm{~m}^{3}$ while the average monthly usage of January, February and JuneDecember is lower with an average monthly consumption of $212,096.11 \mathrm{~m}^{3}$ shows that more concessionaires are consuming in the dry season rather than Rainy Season.

In 2018, the table presents with a peak of consumption in December which is $254,329 \mathrm{~m}^{3}$ and a peak in supply in May which is $303,828 \mathrm{~m}^{3}$, respectively, there is a large amount of usage in water between the month of March-May with an average of $224,134 \mathrm{~m}^{3}$ while the average monthly usage of January, February and June-December is lower with an average monthly consumption of $212,096.11 \mathrm{~m}^{3}$ shows that more concessionaires are consuming in the dry season rather than Rainy Season

\section{CONCLUSIONS}

The result of the data which were the Monthly Data Sheet from Production Division of Santa Rosa (N.E.) Water District provided some evidence about how the climate impacted the demand and supply on the concessionaires on the area. It was shown more concessionaires are consuming in the dry season rather than in rainy season from the year 2016-2018.They have the highest water supply in 2018 and consume more water percentage in 2017.

\section{REFERENCES}

[1] Union of Concerned Scientists. (2010). Water and climate change.https://www.ucsusa.org/resources/water-and-climatechange

[2] Better Health Channel (2014). Water-Vital Nutrient https://www.betterhealth.vic.gov.au/health/healthyliving/wate r-a-vital-nutrient

[3] Sta. Rosa. (NE) Water District. http://santarosawater.gov.ph/index.php/about-us

[4] Kumar, R. (2014). Research Methodology: A Step-byStep Guide for Beginners (4th ed.) SAGE. CA: Thousand Oaks.

[5] Zabala Jr., B., Gutierrez, M. and Subia, G. (2018) Needs Assessment of Barangay Tanawan, Dingalan, Aurora towards a Proposed Oplan Development Program. International Journal of Environment, Agriculture, and Biotechnology, 3, 2163-2167. https://doi.org/10.22161/ijeab/3.6.28

[6] Subia, G. (2018) Comprehensible Technique in Solving Consecutive Number Problems in Algebra. Journal of Applied Mathematics and Physics, 6, 447-457. doi: 10.4236/jamp.2018.63041.

[7] R.C. Sarker, S. Gato-Trinidad and and M. Imteaz. 2013. Temperature and Rainfall Thresholds corresponding to water consumption in Greater Melbourne, Australia. 20th International Congress on Modelling and Simulation, Adelaide, Australia.

[8] Production Division of Sta. Rosa Nueva Ecija Monthly Data Sheet (2016-2018) 